\title{
OPTIMALISASI PEMAKAIAN SHORE CRANE DALAM PEMBONGKARAN MUATAN CONCENTRATE DI PELABUHAN KHUSUS PT. SMELTING GRESIK
}

\author{
Muhammad Arif Rahmat ${ }^{1}$ Cahya Fajar Budi Hartanto ${ }^{2 *}$ Gita Kusumawardani ${ }^{2}$ \\ ${ }^{1}$ Alumnus, Politeknik Bumi Akpelni \\ Jl. Pawiyatan Luhur II No. 17 Bendan Dhuwur, Semarang \\ ${ }^{2}$ Program Studi Nautika, Politeknik Bumi Akpelni \\ Jl. Pawiyatan Luhur II No. 17 Bendan Dhuwur, Semarang \\ Email : fajar@akpelni.ac.id
}

\begin{abstract}
Abstrak
Penelitian ini bertujuan untuk mengungkapkan permasalahan yang terjadi dalam kegiatan pembongkaran muatan curah jenis concentrate di pelabuhan khusus PT. Smelting Gresik dan mencoba memberikan solusinya. Permasalahan tersebut mengakibatkan keterlambatan proses operasi kapal di pelabuhan sehingga proses produksi di perusahaanjuga menjadi kurang efektif dan efisien. Pengumpulan data dilakukan dengan melakukan wawancara kepada pihak terkait serta observasi langsung selama 9 bulan di MV. Arfianie saat sandar dan melakukan kegiatan pembongkaran di pelabuhan. Metode penelitian adalah kualitatif dengan menggunakan analisis deskriptif. Berdasarkan hasil pengamatan, disimpulkan bahwa terdapat 2 penyebab kurang optimalnya pemakaian shore crane. Pertama, karena kurang terampilnya operator yang mengoperasikan shore crane. Kedua, karena faktor dari peralatan itu sendiri yang jumlahnya terbatas sehingga tingkat pemakaiannya cukup tinggi tetapi perawatannya kurang. Berdasarkan permasalahan tersebut, peneliti merekomendasikan adanya pendidikan dan pelatihan untuk operator crane dan tenaga kerja bongkar muat serta jika memungkinkan diadakannya regenerasi dengan yang lebih muda dan profesional. Selain itu, juga harus dilakukan peningkatan perawatan secara berkala. Dengan demikian diharapkan tidak ada kendala lagi yang dapat menghambat operasional kapal maupun perusahaan itu sendiri.
\end{abstract}

Kata Kunci : shore crane, pembongkaran, concentrate

\section{PENDAHULUAN}

\section{Latar Belakang}

Negara Indonesia merupakan negara kepulauan yang sebagian besar wilayahnya berupa lautan yang merupakan prasarana transportasi penting terutama untuk transportasi barang maupun penumpang, oleh sebab itu maka angkutan laut dan pelabuhan beserta fasilitasnya merupakan sarana yang penting dalam mendukung arus perdagangan, baik perdagangan antar pulau dalam wilayah Indonesia maupun perdagangan luar negri.

Dewasa ini dunia pelayaran niaga memegang peranan penting terutama dalam perdagangan ekspor-impor, sehingga terjalin hubungan antara kegiatan perniagaan dengan kegiatan pelayaran, meskipun pada kenyataanya kegiatan melalui usaha pelayaran mengandung resiko tinggi. Namun demikian pada dasarnya penggunaan jalur angkutan laut lebih murah dan efektif dibandingkan dengan menggunakan jalur angkutan lainnya. Berbicara dengan dunia pelayaran niaga tidak terlepas dari kegiatan pembongkaran dan pemuatan, pengangkutan barang dari satu pelabuhan muat ke pelabuhan tujuan. Sedangkan pembongkaran dan pemuatan itu sendiri dikelola oleh perusahaan bongkar muat yang mempunyai tugas dan tanggung jawab mulai dari pengangkatan barang dari kapal sampai barang tersebut ke gudang pelabuhan. Dalam pelaksanaan pembongkaran muatan tersebut sering terjadi keterlambatan, sehingga kapal sandar di dermaga lebih lama dari waktu yang sudah ditetapkan sebelumnya. Banyak masalah yang timbul dalam penanganan bongkar muatan Bulk Cargo diantaranya: terbatasnya peralatan bongkar 
muat, tingkat kemampuan para pekerja bongkar muat serta keterampilan para pekerja tersebut pula, maka dari itu untuk memperlancar proses bongkar muat tersebut diperlukan tenaga ahli dan tenaga kerja atau buruh bongkar muat yang professional dan peralatan bongkar muat yang baik pula kondisinya guna untuk kelancaran kegiatan bongkar muat tersebut. Kegiatan bongkar muat di pelabuhan laut dapat dikatakan lebih sulit dan rumit bila dibandingkan dengan kegiatan bongkar muat di terminal angkutan darat. Sebagaimana diketahui bahwa kegiatan bongkar muat dipelabuhan laut harus melibatkan banyak pihak atau instansi terkait, terlebih bila komoditas (barang dagangan) barang ekspor atau impor. Kegiatan yang umumnya terjadi di pelabuhan adalah kegiatan bongkar muatan agar proses bongkar muat tersebut berhasil dengan baik haruslah mengikuti prinsipprinsip dari pemadatan muatan.

\section{METODE}

Untuk mendapatkan hasil penulisan yang baik, maka data dan informasi yang dipergunakan harus lengkap dan objektif serta dapat dipertanggung jawabkan. Oleh karena itu, dalam penyusunan dan penulisan karya tulis ilmiah ini, Penulis menggunakan metode sebagai berikut :Metode Observasi

Metode Observasi merupakan suatu metode pengumpulan data oleh Penulis dengan melakukan pengamatan secara langsung terhadap kegiatan bongkar muatan konsentrat oleh $M V$.ARFIANIE di pelabuhan khusus PT. SMELTING Gresik.

\section{Metode Studi Pustaka}

Metode Studi Pustaka merupakan suatu metode pengumpulan data oleh Penulis dengan melakukan pencarian referensi yang terdapat di dalam buku maupun internet sehingga data - data ini dapat dijadikan pola pikir dalam mengembangkan pembahasan dan sebagai pelengkap data apabila terdapat kesulitan pemecahan masalah dalam penulisan dengan mempelajari teori - teori yang berhubungan dengan pokok masalah.

\section{LANDASAN TEORI}

Menurut Peraturan Pemerintah Tentang Kepelabuhanan Nomor 69 tahun 2001 bab I pasal 1, pelabuhan adalah tempat yang terdiri dari daratan dan perairan di sekitarnya dengan batas-batas tertentu sebagai tempat kegiatan pemerintahan dan kegiatan ekonomi. Dalam hal ini, pelabuhan dipergunakan sebagai tempat kapal bersandar, berlabuh, naik-turun penumpang dan atau bongkar muat barang yang dilengkapi dengan fasilitas keselamatan pelayaran dan kegiatan penunjang pelabuhan serta sebagai tempat perpindahan intra dan antar moda transportasi. Sedangkan Pengertian Pelabuhan Khusus dari buku Manajemen Kepelabuhan (2000: 13) adalah Pelabuhan yang digunakan secara khusus oleh sektor perindustrian, pertambangan atau pertanian, yang pembangunan dan pengoperasiannya dilakukan oleh instansi yang bersangkutan untuk melakukan kegiatan bongkar muat bahan baku dan hasil produksinya yang tidak dapat ditampung oleh pelabuhan umum. Pelabuhan-pelabuhan khusus tersebut, antara lain meliputi : pelabuhan khusus pertanian, pelabuhan khusus perikanan, pelabuhan khusus perkayuan dan pelabuhan khusus industri.

Menurut Ibester (1993 : 79), dalam buku Bulk Carrier Practice mengemukakan baahwa Bulk Cargo atau muatan curah adalah muatan yang diangkut didalam tangki atau palka muatan dan tidak dikapalkan dalam drum, kaleng atau bungkusan. Produk muatan yang berbentuk curah terdiri dari berbagai macam. 
Berdasarkan ukuran bobot mati, tipe bulk carrier di bedakan menjadi :

1. Handy size Bulk Carrier

berukuran 10000-35000

DWT

2. Handy max Bulk Carrier

berukuran 35000-50000

DWT

3. Panamax Bulk Carrier

berukuran 50000-80000

$D W T$

4. Capasize

berukuran

lebih dari

80000 DWT

Menurut Herry Gianto dan Arso Martopo (1990:30) dalam buku Pengopersian Pelabuhan Laut, pengertian bongkar muat adalah Jasa pelayanan membongkar dari/ke kapal, dermaga, tongkang, truck atau muat dari/ke dermaga, tongkang, truck ke/dalam palka dengan menggunakan derek kapal atau yang lain.

Menurut Istopo ( 1999:17) dalam bukunya Kapal dan Muatannya mengemukakan bahwa Alat-alat bongkar yang tersedia digunakan untuk menyelenggarakan bongkar muatan. Peralatan muat bongkar adalah suatu susunan dari berbagai alat sedemikian rupa dari dan ke dalam kapal. Adapun susunan tersebut terdiri dari batang pemuat, tiang pemuat, mesin derek yang sudah dilengkapi dengan berbagai jenis block dan tali temali. Untuk kapal cargo moderen sering digunakan keran dek (deck crane) sebagai alat bongkar muat sesuai dengan jenis barang yang diangkut misalnya conveyor dan escavator untuk kapal curah, berbagai jenis pipa dan pompa untuk kapal tanker dan IPG. Agar peralatan dapat bekerja optimal dan aman, maka perlu dilakukan perawatan. Menurut Isbester (1993:273-274) aturan dasar dari sebuah perawatan adalah.

a. Harus teliti

b. Harus memiliki cara / methodical c. Merencana pekerjaan pemeliharaan terlebih dahulu.

d. Diskusikan dengan pihak lain dan tetap memberikan informasi.

e. Mempelajari Panduan dari buku manual.

f. Gunakan bahan dan peralatan yang benar.

g. Jangan mempercayakan pada anggota yang tidak berpengalaman.

h. Tetap membuat catatan kerja setiap selesai pemakaian.

Muatan curah menurut Sudjatmiko (1995:67) adalah adalah muatan yang terdiri dari suatu muatan yang tidak dikemas yang dikapalkan sekaligus dalam jumlah besar. Muatan curah dibagi menjadi muatan curah kering, muatan curah cair (liquid bulk cargo), muatan curah gas. Sedangkan muatan concentrate menurut S. Nurlailasari (2017) concentrate yakni muatan berupa pasir tambang yang sangat halus, berwarna hitam pekat yang dapat larut dengan mudah apabila terkena air, serta muatan ini mengandung mineral seperti: seng, tembaga, emas, perak, timbal, kobalt dan besi.

\section{HASIL DAN PEMBAHASAN}

Faktor yang menyebabkan terjadinya keterlamabatann pada saat pembongkaran

1. Adanya operator crane darat yang

kurang terampil

Operator crane darat merupakan tenaga kerja yang melakukan kegiatan bongkar muatan batu bara dari kapal ke conveyor, sehingga cepat tidaknya bongkar muatan batu bara juga dipengaruhi oleh operator crane. Berdasarkan observasi di lapangan, dan diperkuat penjelasan dari Bapak Imaningkas selaku kepala operasional dijumpai adanya operator crane yang kurang terampil dalam pengoperasian crane sehingga mengganggu kelancaran 
proses bongkar muatan curah concentrate di pelabuhan khusus PT SMELTING Gresik. Kelancaran produktivitas operator crane di dermaga sering mengalami masalah yang tidak terlepas dari operator crane itu sendiri, yaitu kurang terampilnya mengoperasikan crane dalam proses bongkar muat yang sedang berlangsung. Berdasarkan fakta di lapangan pada tanggal 11 Juli 2017, penulis menjumpai adanya kasus kejadian pada proses bongkar concentrate berlangsung yaitu grabe (penggaruk) menggaruk keras pada lantai palka yang mengakibatkan lantai palka mengalami kebocoran pada ballast tank.

2. Terjadi kendala pada alat bongkar muat Peralatan bongkar muat merupakan alat-alat pokok penunjang pengerjaan bongkar muat, kecepatan pengoperasian peralatan dan daya angkut. Secara umum usia peralatan bongkar muat sangat berpengaruh terhadap kinerja dari alat itu sendiri apalagi dengan terbatasnya peralatan yang memaksa peralatan tersebut bekerja secara terus menerus. Semakin lama peralatan bongkar dioperasikan semakin besar pula kemungkinan kerusakan yang akan terjadi oleh peralatan bongkar muat tersebut. Hal ini sangat wajar mengingat dalam pengoperasian alat bongkar muat tergolong pekerjaan yang membutuhkan daya yang besar sehingga dalam jangka waktu tertentu mesin rentan mengalami hambatan atau kerusakan, dan juga kurangnya perawatan terhadap peralatan yang berdampak pada produktivitas bongkar tersebut.

Fakta ini diperkuat dari pengamatan yang dilakukan penulis pada tgl 22 Januari 2018 di Pelabuhan PT. SMELTING Gresik, beserta melampirkan data pendukung dari pengambilan foto yang menunjukan kerusakan pada alat bongkar.

Peralatan bongkar muatan batu bara yang sering mengalami kerusakan adalah :
a. Wire Crane yang putus
b. Penyangga Roller Belt yang patah
c. Roller belt conveyor yang patah

\section{Upaya - upaya yang di lakukan untuk menanggulangi hambatan dalam proses bongkar muatan concentrate di pelabuhan PT.SMELTING Gresik.}

1. Pendidikan dan Pelatihan

a. Pendidikan dan pelatihan untuk

Operator Crane

Untuk meningkatkan produktivitas bongkar muatan di Pelabuhan PT. SMELTING Gresik khususnya pada operator crane adalah dengan meningkatkan ketrampilan dari para operator crane dengan mengadakan pendidikan dan pelatihan. Pembinaan yang dilakukan untuk meningkatkan pengetahuan ketrampilan, sehingga operator crane terangsang untuk meningkatkan kinerja dalam bongkar muat, kepada para operator crane dari peralatan-peralatan bongkar muat diwajibkan memiliki Sertifikat Operator dan Surat Ijin Operator dari Departemen Tenaga Kerja yang bekerja sama dengan Departemen Perhubungan Laut. Untuk mendapatkan tenaga kerja yang terampil dilakukan tahapan-tahapan, sebagai berikut

1) Pelatihan teori kepada operator crane

2) Pelatihan praktek lapangan

Dengan tahapan ini dapat diketahui kemampuan tiap operator crane dalam cara penggunaan dan cara mengatasi masalah pada crane darat yang dioperasikan tersebut.

Adapun tujuan diadakan pendidikan dan pelatihan bagi operator crane adalah untuk meningkatkan kedisiplinan kerja serta untuk menambah kemampuan serta keahlian dalam mengoperasikan crane 
darat yang mengarah pada kualitas dan peningkatan produktivitas bongkar muatan di pelabuhan khusus PT. SMELTING Gresik. Bila semua itu dapat dilaksanakan, maka dengan demikian dalam hal pekerjaan akan dapat dicapai hasil produktivitas kerja sesuai yang diharapkan. Berikut ini penulis juga melampirkan daftar-daftar peserta diklat

Tabel 1 : Daftar Peserta Diklat Operator Crane Tahun 2017

\begin{tabular}{|l|l|l|}
\hline No & Nama peserta & Reg/ TKBM \\
\hline 1 & Iswahyudi & 0232 \\
\hline 2 & Sujono & 0274 \\
\hline 3 & Kaselun & 0275 \\
4 & Ach.Nursaid & 0267 \\
5 & Iskandar & 0268 \\
6 & Arif Wahyudi & 0126 \\
7 & Agus Hartono & 0122 \\
8 & Matdullah & 0123 \\
9 & Mahfud & 0134 \\
10 & M.Masyhuri & 0133 \\
11 & Halil & 0137 \\
12 & H.Saleh & 0142 \\
13 & Mudjiadi & 0145 \\
14 & Mustar & 0149 \\
15 & Slamet Haryono & 0315 \\
16 & Djiwanto & 0318 \\
17 & Budi Santoso & 0320 \\
18 & Achmad Cholil & 0322 \\
19 & Nurdianto & 0328 \\
20 & Susanto & 0330 \\
\hline
\end{tabular}

Sumber : Hasil observasi dan tanya jawab kepada Foreman dilapangan
Diklat operator crane merupakan tempat evaluasi bagi peserta diklat yang merupakan tenaga kerja bongkar muatan PT. SMELTING Gresik untuk meningkatkan kemampuan serta kecakapan peserta pada saat melakukan pembongkaran muatan. Selain daripada hal tersebut, diklat juga merupakan pengalihan aktifitas yang tepat bagi peserta diklat dari kesibukan bongkar muatan sehari hari, sehingga dapat mengurangi tingkat stres dalam bekerja. 
Tabel 2 :Perbedaan Produktivitas Kerja antara Operator Crane yang Berpendidikan Formal Ditambah Kursus Operator dengan Operator Crane yang Belum Mengikuti Kursus Operator

\begin{tabular}{|c|c|c|c|}
\hline \multirow{2}{*}{ NO } & \multirow{2}{*}{ Kemampuan } & \multicolumn{2}{|c|}{ Operator Crane menurut level Pendidikan } \\
\hline & & Setelah mengikuti kursus & Sebelum mengikuti kursus \\
\hline 1 & $\begin{array}{l}\text { Kemampuan mengoperasikan } \\
\text { alat mekanis }\end{array}$ & $\begin{array}{l}\text { Tidak perlu lagi } \\
\text { dibantu ( dipandu ) }\end{array}$ & Masih harus dipandu \\
\hline 2 & $\begin{array}{l}\text { Kemampuan menerjemahkan } \\
\text { label- label alat mekanis }\end{array}$ & Lancar & Kurang Lancar \\
\hline 3 & Kedisiplinan dalam bekerja & Lebih Tinggi & Cukup \\
\hline 4 & Kehati-hatian dalam bekerja & Lebih Tinggi & Kurang \\
\hline 5 & $\begin{array}{l}\text { Kesadaran untuk mematuhi } \\
\text { perintah atasan }\end{array}$ & Lebih Baik & Cukup \\
\hline 6 & $\begin{array}{l}\text { Kesadaran untuk bekerja } \\
\text { sebaik-baiknya dengan penuh } \\
\text { tanggung jawab }\end{array}$ & Baik & Cukup \\
\hline 7 & $\begin{array}{l}\text { Kesadaran untuk mematuhi } \\
\text { aturan }\end{array}$ & Lebih Tinggi & Kurang \\
\hline
\end{tabular}

Sumber : Hasil observasi di lapangan

Dari tabel yang tertera diatas dapat ditarik kesimpulan bahwa pentingnya Pelatihan ketrampilan bagi operator crane guna meningkatkan produktivitas dan kelancaran bongkar muatan concentrate di Pelabuhan Khusus PT. SMELTING Gresik.

b. Pendidikan dan Pelatihan untuk TKBM

Untuk meningkatkan kualitas salah satu upaya yang dilakukan adalah dengan mengadakan pendidikan dan pelatihan kepada para Kepala Regu Kerja ( KRK ) guna meningkatkan kemampuan dan ketrampilannya, adapun tujuan diadakannya pendidikan dan pelatihan bagi kepala regu kerja adalah untuk meningkatkan kedisiplinan kerja serta menumbuhkan jiwa kepemimpinan yang mengarah pada peningkatan kualitas TKBM dan peningkatan produktifitas bongkar muat di Pelabuhan PT. SMELTING Gresik, berikut ini data-data diklat kerja TKBM . 1) Peningkatan Pemeliharaan dan Perawatan

Pemeliharan dan Perawatan adalah suatu sistim dari pengadaan aktivitas fisik yang berupa peralatan bongkar muat dalam rangka mempertahankan kondisi fasilitas dan peralatan pada keadaan siap guna dan laik operasi. Aktifitas pemeliharaan dan perawatan merupakan keterpaduan dari beberapa aspek yang perlu dipertimbangkan guna menjaga kondisi peralatan bongkar muat tersebut Pemeliharaan dimaksudkan untuk mendapat jaminan produktivitas dan kualitas melalui upaya peningkatan efektifitas penggunaan. Pemeliharaan dilakukan agar perusahaan berhasil meningkatkan kemampuan dalam proses bongkar muat. Selain pemeliharaan juga dilakukan perbaikan sebagai kegiatan yang mencakup seluruh upaya yang dilaksanakan dalam rangka memperbaiki 
kerusakan yang terjadi pada peralatan bongkar muat dan mencegah munculnya gangguan yang sering terjadi.

2) Penetapan jadwal perawatan dan pemeliharaan

Penetapan dan pemberlakuan jadwal pemeliharaan dan perawatan akan sangat membantu dalam upaya menciptakan kondisi peralatan bongkar muat yang baik dan selalu siap untuk dioperasikan. Sebagai upaya tetap terlaksananya jadwal pemeliharaan dan perawatan yang rutin, perusahaan dapat mengambil kebijakan lain yang mendorong tetap terlaksananya pemeliharaan dan terlaksananya perawatan, yaitu dengan menugaskan salah satu karyawan yang bertanggung jawab untuk selalu mengawasi dan menjamin tetap terlaksananya perawatan, Dengan adanya penetapan jadwal perawatan dan pemeliharaan tersebut maka karyawan mempunyai kewajiban untuk melakukan pekerjaanya. Tentunya hal ini juga dibutuhkan kesadaran diri dari tenaga mekanik tersebut, di sisi lain perusahaan juga menyediakan spare part peralatan bongkar, dengan persediaan ( stock ) spare part maka akan sangat berpengaruh terhadap proses perawatan.

3) Koordinasi ( Organizing )

Koordinasi pihak kapal dilakukan baik oleh pihak kapal sendiri maupun oleh pihak pelabuhan

a) Koordinasi pihak kapal dengan pihak kapal sendiri, yaitu, koordinasi antara pimpinan kapal atau Nahkoda kepada Mualim yang bertanggung jawab terhadap muatan. Dan kordinasi antara Mualim I dengan mualim jaga saat proses bongkar berlangsung.

b) Kordinasi pihak kapal dengan pihak pelabuhan, yaitu, koordinasi antara perwira kapal yang bertanggung jawab terhadap muatan dalam hal ini mualim I terhadap pihak pelabuhan di Gresik baik pihak keagenan, Pengirim muatan, Penerima muatan, Syahbandar, operator crane, tenaga Kerja Buruh dan Jetty management. c) Pelaksanaan ( Actuating )

Pada saat pelaksanaan pihak kapal dan pihak pelabuhan harus berkoordinasi penuh dan harus mengawasi jalannya proses bongkar sampai selesai sehingga tercipta suatu manajemen proses bongkar yang aman, cepat, lancar dan sistematis, sehingga keterlambatan dalam proses bongkar dapat diatasi.

2. Perawatan terhadap alat Bongkar Dari hasil penelitian dapat diketahui bahwa peralatan bongkar muat yang ada di Pelabuhan PT. SMELTING Gresik harus bekerja secara terus menerus, karena keterbatasan pada peralatan bongkar muat. Disebabkan ada beberapa alat bongkar muat yang rusak, sedangkan perawatan dan pemeliharaan dari peralatan bongkar muat kurang dilaksanakan secara rutin dan teratur oleh para pengguna peralatan bongkar muat, sedangkan kegiatan bongkar muatan concentrate terus berlangsung guna memenuhi proses produksi daripada PT. SMELTING Gresik

Dari hasil wawancara yang penulis lakukan pada tanggal 08 Agustus 2017, penulis mendapatkan data-data keterangan hasil wawancara dari Bapak Edi Sulistiono selaku kepala Perawatan peralatan bongkar di wilayah dermaga . Perawatan selalu dilaksanakan oleh pihak Pelabuhan yang terkait guna mengacu pada proses bongkar muatan yang aman, cepat dan sistematis sehingga keterlambatan dalam proses bongkar dapat diatasi. Pengawasan ini terbagi dalam tiga tahap

a. Perawatan berkala harian, yang dilakukan oleh pihak pelabuhan pada alat-alat bongkar seperti perawatan secara visual pada crane, unloader, grab, belt, conveyor dan rollerbelt. Hal ini dilakukan baik pada saat proses bongkar berlangsung maupun pada saat tidak terdapat proses bongkar

b. b. Perawatan berkala bulanan, yang dilakukan oleh pihak pelabuhan baik dari Cargo Operation 
maupun Jetty Operation. Seperti pengawasan sekaligus pemeriksaan pada alat bongkar dan dermaga.

c. Perawatan berkala tahunan, merupakan hasil tinjauan ulang perawatan berkala harian dan berkala bulanan yang telah dilakukan oleh pihak perusahaan.

\section{KESIMPULAN}

Berdasarkan penelitian yang telah dilakukan oleh penulis selama melaksanakan penelitian di pelabuhan PT. SMELTING Gresik, maka penulis dapat menyimpulkan dari permasalahan yang terjadi tersebut.

1. Produktivitas kegiatan bongkar muat yang terhambat dikarenakan kurangnya ketrampilan para operator crane dalam penggunaan peralatan bongkar muat dan juga dikarenakan kondisi peralatan yang tidak sesuai serta ada kerusakan beberapa peralatan bongkar muat, dan tidak adanya perawatan dan pemeliharaan untuk peralatan bongkar muat serta banyaknya tenaga kerja bongkar di Pelabuhan PT. SMELTING Gresik yang usianya sudah lanjut dan yang seharusnya sudah pensiun kerja tetapi masih digunakan dan masih dipekerjakan.

2. Pelabuhan PT. SMELTING Gresik telah melakukan langkah-langkah mengatasi hambatan dengan memberikan pelatihan keterampilan operator crane dan perawatan rutin terhadap peralatan bongkar, sehingga hambatan-hambatan tersebut dapat diminimalkan.

\section{DAFTAR PUSTAKA}

Istopo. 1999. Kamus Istilah Pelayaran \& Ensiklopedi Maritime. Yayasan C.A.A.I.P./P.L.A.P. Jakarta

J. Isbester. 1993. Bulk Carrier Practice. Nautical Institute.
Sudjatmiko, F. D. C. 1995. Pokok-pokok Pelayaran Niaga. Gunung Agung. Jakart 